IZA DP No. 4380

Why Do Firms Use Fixed-Term Contracts?

Pedro Portugal

J osé Varejão

August 2009 


\title{
Why Do Firms Use Fixed-Term Contracts?
}

\author{
Pedro Portugal \\ Banco de Portugal, \\ Universidade NOVA de Lisboa and IZA \\ José Varejão \\ Universidade do Porto \\ and IZA
}

\section{Discussion Paper No. 4380 \\ August 2009}

\author{
IZA \\ P.O. Box 7240 \\ 53072 Bonn \\ Germany \\ Phone: +49-228-3894-0 \\ Fax: +49-228-3894-180 \\ E-mail: iza@iza.org
}

\begin{abstract}
Any opinions expressed here are those of the author(s) and not those of IZA. Research published in this series may include views on policy, but the institute itself takes no institutional policy positions.

The Institute for the Study of Labor (IZA) in Bonn is a local and virtual international research center and a place of communication between science, politics and business. IZA is an independent nonprofit organization supported by Deutsche Post Foundation. The center is associated with the University of Bonn and offers a stimulating research environment through its international network, workshops and conferences, data service, project support, research visits and doctoral program. IZA engages in (i) original and internationally competitive research in all fields of labor economics, (ii) development of policy concepts, and (iii) dissemination of research results and concepts to the interested public.
\end{abstract}

IZA Discussion Papers often represent preliminary work and are circulated to encourage discussion. Citation of such a paper should account for its provisional character. A revised version may be available directly from the author. 
IZA Discussion Paper No. 4380

August 2009

\section{ABSTRACT}

\section{Why Do Firms Use Fixed-Term Contracts?*}

Temporary forms of employment account for a variable but never trivial share of total employment in both the U.S. and in Europe. In this article we look at how one specific form of temporary employment - employment with fixed-term contracts - fits into employers' hiring policies. We find that human capital variables (schooling, skills and employer-provided training) as measured at the levels of the worker and the workplace are important determinants of the employers' decisions to hire with fixed-term contracts and to promote temporary workers to permanent positions. Those employers that hire more with fixed-term contracts are also those that are more likely to offer a permanent position to their newly-hired temporary employees. Our results indicate that fixed-term contracts are used as mechanisms for screening workers for permanent positions.

JEL Classification: J23, J41

Keywords: fixed-term contracts, adjustment costs, labor demand

Corresponding author:

José Varejão

Faculdade de Economia

Universidade do Porto

Rua Dr Roberto Frias

4200-464 Porto

Portugal

E-mail: varejao@fep.up.pt

\footnotetext{
* We would like to thank David Autor, Olivier Blanchard, Dan Hamermesh, Francis Kramarz, and Juan Dolado for their helpful comments. The authors also gratefully acknowledge the partial financial support of the Fundação para a Ciência e a Tecnologia. We also thank the Departamento de Estatística do Ministério do Trabalho that kindly allowed us to use the data. The usual disclaimer applies. CEF.UP is also funded by the Fundação para a Ciência e a Tecnologia.
} 


\section{Introduction}

In nearly all labor markets, deregulation was the policy response to high and persistent unemployment. In Europe, many countries adopted two-tier reforms that, although they increased flexibility at the margin, left unchanged the mandates applying to already existing contracts. As a result, new contractual arrangements governed by less stringent rules, particularly with regard to firing costs, were introduced and they rapidly gained importance. In the U.S.A., where no similar rigidities could be found, it was also the case that new forms of work developed.

Rationalization of the growing share of these work arrangements has been offered within a labor adjustment cost framework. In this context, firms hire contingent workers because they want to save on future dismissal costs, regardless of their origin. Notwithstanding, the focus on adjustment costs alone may be too narrow. Some studies dispute the common view that fixed-term contracts actually offer firms increased flexibility due to restrictions that typically apply to the rolling over of these contracts (Hunt, 2000; Maurin, 2000). In the same vein, a number of reasons for using fixed-term contracts, other than saving on prospective firing costs, have been considered. These are mainly cost saving reasons (especially savings on fringe benefits), temporary replacement, and screening for permanent positions.

Nevertheless, using fixed-term contracts to fill permanent positions may be part of the firm's personnel policy. Churning (worker turnover in excess of job turnover), has been earlier reported as a permanent feature of some firms' employment records, and not simply the inevitable response to unfortunate matches (Burgess et al., 2000). Such policies may be rationalized within an efficiency wage framework, where firms are thought of as choosing different combinations of wage rates and worker turnover at continuing positions. Firms choose one type of strategy over the other depending on the fundamentals of their technology, skills, and

cost structure. Costly monitoring and training are likely to be associated with a high wage - low turnover strategy, as are higher average skill level and more 
efficient hiring technologies (Lane et al., 1996).

However, churning strategies may also be rationalized within a simple labor adjustment cost framework. Because the cost of firing one worker with a temporary contract is reduced, firms may be more willing to hire new workers and examine them on the job. But due to the presence of non-renewal clauses, firms may prefer to fire the worker while his contract is temporary and take a chance on a new one (Blanchard and Landier, 2002). The result is persistent match destruction at continuing positions, i.e., churning.

It is mainly the possibility that employers use fixed-term contracts for churning that raises policy concerns. In fact, the implications of fixed-term contracts for long-term productivity growth depend crucially upon the reasons why employers use them.

If fixed-term contracts are used as buffer stocks, implications are mixed. Flexible contracts facilitate firing in downturns, reducing labor hoarding and fostering productivity. However, because they reduce job stability, the use of fixed-term contracts as buffer stocks also hinders match-specific learning-by-doing and investments in training, thereby harming long-run growth prospects. On the contrary, if fixed-term contracts are used as screening devices, they generate better growth prospects due to better learning about match quality, which translates into better job matches and, therefore, more stable employer-employee relationships (Nagypál, 2001). ${ }^{1}$ However, if fixed-term contracts are used for churning workers, they unequivocally have adverse effects in terms of productivity growth, again because they reduce match-specific learning-by-doing and investments in training, and because otherwise good matches are more often terminated and replaced with new ones of an uncertain value (Blanchard and Landier, 2002).

Assessing the role that fixed-term contracts play in employers' staffing policies is essentially an empirical problem for which only limited evidence is available. Disentangling the alternative uses of temporary contracts has proven a difficult task.

\footnotetext{
${ }^{1}$ Furthermore, Faccini (2007) shows that a matching model where firms use temporary contracts to screen workers for permanent positions accounts for the positive correlation between temporary contracts and the employment rate.
} 
The standard approach to the problem is to focus on transitions from temporary to permanent contracts. The implicit assumption is that if temporary contracts are used as screening devices, transitions to permanent positions will be more frequent than is the case when those contracts are used for alternative purposes such as buffer stocks or churning. However, lower firing costs bias the employer's choice towards less pre-hiring and more on-the-job screening. The result is that the rate of sucessful matches is now reduced, i.e., transitions to permanent positions less frequent. Hence, the identification of the reasons why employers use these contracts is somewhat blured.

In this article we take a different approach to the same problem. We pose four questions to which we offer clear evidence obtained from one longitudinal matched employer-employee dataset. These questions are: (i) which employers use temporary contracts?; (ii) which employees are hired with temporary contracts?; (iii) which employers convert temporary contracts to permanent?; (iv) which employees get promoted from temporary to permanent positions? By looking simultaneously at the employer and the employee sides and at the hiring and promotion stages, we will be able to produce evidence that answers these four questions and sheds light on how and why employers use fixed-term contracts. Our interest is in how human capital intensity, in terms of the skill-structure of the workforce and firmprovided training, shapes the employer decision vis-à-vis temporary contracts. Direct evidence on vacancies and replacement hires will also be considered. From the employee-side, educational attainment and labor market experience are the main focus of our attention. The timing of contract conversion is also of interest.

We also depart from previous studies of the same issue by using a different type of data. Whereas previous studies use employee data obtained from domestic Labor Force Surveys, we use matched employer-employee data. Our data is for Portugal.

Fixed-term contracts represent a non-trivial share of total employment in the Portuguese labor market (17.6 percent, on average, for the period between 1995 and 2003). In 2003, Portugal exhibited the second largest share of fixed-term contracts 
in total employment within the 15 EU member States where fixed-term contracts accounted for an average of 12.8 percent of total employment (Portugal, with 20.6 percent in the same year, was second only to Spain, which exhibited a record mark of 30.6 percent - European Commission, 2004). Quarterly data available for the period between 1991 and 1998 indicate that fixed-term contracts account for an average of 62 percent of all accessions and 43 percent of all separations in the Portuguese labor market (source: Employer Employment Survey).

The Portuguese case is of interest not only on quantitative grounds but also because it is a case where strict overall employment protection legislation is accompanied by relatively mild regulation of temporary forms of employment. ${ }^{2}$ This is, in fact, weaker in Portugal than in other European countries with strict protection rules against individual dismissal, such as France, Spain or Greece. This is to some extent specific to the Portuguese case, as high-EPL countries typically have strict regulation on temporary forms of employment. ${ }^{3}$

The article is organized as follows. Section 2 presents the empirical strategy. Data are described in Section 3. Results are discussed in Section 4. Section 5 concludes.

\section{Estimation strategy}

\subsection{The beta-binomial regression model}

To address the two questions on the employer side - which employers use temporary contracts and which employers convert temporary contracts to permanent? - we use fractional regression models.

The first model focuses on the employer's decision to offer a fixed-term contract as an alternative to standard (open-ended) contracts. The dependent variable is

\footnotetext{
${ }^{2}$ On the conspicuous nature of the Portuguese labor market, see Blanchard and Portugal (2001) and Varejão and Portugal (2007).

${ }^{3}$ The strictness of the overall EPL legislation is especially due to the protection of permanent workers against individual dismissal. As a result, Portugal occupies the first position (alongside Turkey) in the OECD ranking of the most stringent employment protection legislation in Europe, although it occupies an intermediate position if we only consider the regulation of temporary employment (OECD, 1999 and 2004). Legislation on dismissals and fixed-term contracts did not change significantly over the period covered by our analysis (1995-2003). With minor amendments, the law on fixed-term contracts dates back to 1989 and the law on dismissals to 1991. They were both in place until 2004, when a new labor law was adopted.
} 
the number of fixed-term contracts existing at the firm at a certain point in time (the number of events) out of the total number of employees at the firm (the number of trials). In cases like this, a count model applied to proportions (of which the Poisson regression model is the most commonly assumed) is often used. The same kind of specification would also be indicated for the second regression model where the dependent variable is the number of fixed-term contracts that were converted to open-ended (the number of events) out of the total of fixed-term contracts existing at the firm (the number of trials).

However, if data display overdispersion, the Poisson assumption will fail and generalized count models generated by mixtures of distributions are more adequate. Unobserved heterogeneity or true contagion, may both generate overdispersed data, which is, in fact, a common feature of count data. One way that overdispersion may manifest itself is through a higher relative frequency of zero observations than is consistent with the Poisson assumption. ${ }^{4}$

In these circumstances, the count data models more commonly used in applied work are negative binomial models that may be interpreted as a Poisson-gamma mixture, i.e., a Poisson distribution with unobserved individual (gamma) heterogeneity that also allows for particular forms of dependence for the underlying stochastic process (true contagion). The problem with the negative binomial specification is that it assumes an infinite upper bound for the variable of interest, which makes it inappropriate whenever that upper bound is small, as is the case with the dependent variables of the two regression models being estimated.

In these cases, a beta-binomial model is a useful alternative (Heckman and Willis, 1977). This model assumes that the probability $p$ that the event occurs in any of its $n$ trials depends on a set of unobserved individual characteristics and that this is distributed as a beta random variable with parameters $\alpha$ and $\theta$. Under these assumptions, the dependent count variable $Y$ follows a beta-binomial distribution. ${ }^{5}$

\footnotetext{
${ }^{4}$ Hurdle models are sometimes used to deal with this feature of the data that is commonly referred to as 'excess zeros' or 'zero inflation'.

${ }^{5}$ For a thoughtful presentation of the beta-binomial regression model, see Santos Silva and Murteira (2000). We thank Santos Silva for kindly providing us with the TSP codes for the beta-binomial model.
} 
This beta-binomial regression model stands for the binomial very much in the same way as the negative binomial model stands for the Poisson. This means that it may still be interpreted as a binomial distribution with individual heterogeneity, but also as giving the number of successes when both success and failure are contagious. ${ }^{6}$ The accommodation of true contagion is a welcome feature of this distribution because the dependent variables in the two previously described models may display that property. In fact, if a firm uses fixed-term contracts as a structural component of its staffing policy, the occurrence of an event increases the probability of further occurrences, and conversely. Likewise, in the second model, if firms use fixed-term contracts as part of a strategy of churning workers around a fixed number of positions, failure to convert one contract to a permanent one raises the probability of further failures (Johnson et al., 2005).

\subsection{The complementary log-log hazard model}

To address the two questions on the employee side - which employees are hired with temporary contracts and which employees get promoted from temporary to permanent positions? - we use a binary choice model and a hazard regression model.

Duration analysis provides a convenient statistical framework to study labor market transitions. In such a context, the duration variable measures the worker's tenure on the job. In studies of transitions out of temporary employment, the corresponding duration definition is time since admission with a fixed-term contract (i.e., the tenure on the job of the temporary worker). In our data, duration is measured at discrete intervals (quarters). We thus consider a simple discrete time duration model: the complementary log-log (cloglog) model.

Considering the workers' alternatives, we shall also distinguish between three exit modes from the current temporary employment spell: same employer - openended contract, employed with a different employer, out of the dataset (unem-

\footnotetext{
${ }^{6}$ The estimation procedure automatically weighs each observation by the corresponding risk set. That is, in the incidence of fixed-term contracts equation, the observations are (implicitly) weighted by the number of employees; in the transition to permanent employment equation the observations are weigthed by the number of workers with fixed-term contracts.
} 
ployed, civil servant, independent work status or out of the labor force). Thus, we define cause-specific hazard functions to destination $j$.

The model has a conventional competing risks interpretation. In this framework, a latent duration $\left(T_{j}\right)$ attaches to each exit mode. We only observe the minimum of each latent variable. If risks are assumed to be independent, with continuous duration, this model simplifies to three separate single-cause hazard models. The same simplification can be obtained if we assume that transitions can occur only at the limits of the intervals, which, for the sake of simplicity, we will do.

\section{Data}

In the empirical work we use data from two different sources. The first is a longitudinal firm-level dataset and the second is a matched employer-employee dataset. Both datasets are administrative in nature and are administrated by the Portuguese Ministry of Labor. They are mergeable and at some point we make use of this possibility.

\subsection{The longitudinal employer data}

The Social Audit ('Balanço Social') is an annual survey run by the Portuguese Ministry of Employment. When it was first introduced in 1986 it covered stateowned firms only. Since then, its coverage has expanded, first to firms with at least 500 employees and, since 1992, to all firms with at least 100 employees. For these firms, answering the survey is mandatory.

Each year, a respondent firm reports data on a large variety of topics concerning the characteristics of the workforce and labor costs. This is organized into six major areas: (i) company details; (ii) employment; (iii) labor costs; (iv) occupational safety; (v) vocational training; and (vi) social expenditures.

The employment block, which is the largest component of the survey, collects detailed information on the characteristics of the firm's workforce, namely the total number of workers (year average and end-of-year count), the skill composition, age 
structure, tenure, and the educational level of the workforce. Total employment is also broken down by type of contract. Extensive information on the stock and flows of workers with fixed-term contracts is also available. Reasons why permanent workers left the firm during the course of each calendar year are also reported. The bulk of data used here comes from this block. Other variables refer to wages (wage level and wage dispersion) and costs of vocational training.

Eight waves of the survey were available for this study, covering the period from 1995 to 2002. The dataset we used contains information on an average of 2,100 firms (a total of 16,789 year $\times$ firm observations) and approximately 787,000 workers per year. The number of workers represented in the dataset corresponds to 36 percent of the total number of employees in the Portuguese labor force (excluding civil servants).

The Social Audit enables us to identify the firm-level share of fixed-term contracts in total employment and the proportion of fixed-term contracts that were converted to permanent during the calendar year.

The stock measure of fixed-term contracts was obtained using the total number of such contracts reported by respondents, which refers to the year-end (head count by December 31 st). ${ }^{7}$

However, using the year-end count of fixed-term contracts to compute the corresponding rate of conversion would be inappropriate. Hence, the total numbers of such contracts that existed during the calendar year and that became permanent during the same period were used.

The sole measure of wages reported is the firm-level average for its entire workforce excluding top-level managers. This (unconditional) wage variable simply tells us whether firms are high or low-wage firms, giving us no information on the relative wage of temporary and permanent workers.

\footnotetext{
${ }^{7}$ For consistency, we use the corresponding count of the total number of employees, instead of the year average, which is also reported.
} 


\subsection{Matched employer-employee data}

The Personnel Records ('Quadros de Pessoal') dataset is a matched employeremployee dataset (Personnel Records) that contains information on every wageearner in the Portuguese economy (with the exception of civil servants and independent workers) as well as on their employers (firm-level and establishment-level). These data have been collected since 1985 but it was not until 2002 that information on each worker's type of contract was collected. We restrict our use of these data to their 2002 and 2003 waves, so that we have one year overlap with the Social Audit, thereby keeping the option of merging the two datasets.

From the Personnel Records data we produce two different datasets.

\subsubsection{New-hires dataset}

The new-hires dataset is a subset of the raw 2003 file that contains only the observations corresponding to individuals with tenure less than or equal to three months (i.e., who have been hired by their current employer at some point between July and October 2003). ${ }^{8}$ The sample is further restricted to those employees that work for a firm that is also a respondent to the Social Audit. The original file contains 2,855,599 observations and the restricted file 26,748 observations. We observe the age, gender, education and nationality of all these new hires.

\subsubsection{Fixed-term contract dataset}

The fixed-term contracts dataset is constructed to look at transitions out of temporary employment. Starting with the 2002 file (with a total of 2,693,960 observations) the sample is restricted to those workers $(469,940)$ that are employed with a fixed-term contract and were hired by their current employer at some point between October 1999 and October 2002 (i.e., those whose contract has not yet reached its legal maximum length - 36 months - in 2003). The number of these workers that work for firms that are also respondents to the Social Audit (with at least 100 employees) is 148,764. The worker characteristics as of 2002 are thus ob-

\footnotetext{
${ }^{8}$ Data from Quadros de Pessoal are refer to the month of October of the corresponding year.
} 
tained. The characteristics of the worker's employer are also taken from 2002 data, Personnel Records or Social Audit. From the 2002 file of the Personnel Records dataset we obtain the firms' average monthly wage of permanent workers in 2002 as well as the average pay for an overtime hour of work.

By merging the 2002 and 2003 Personnel Records datafiles we are able to identify the situation of all the workers that in the first year had a fixed-term contract. Four distinct outcomes are considered: i. employed with the same employer and with an open-ended contract; ii. employed with the same employer and still with a fixed-term contract; iii. employed with a different employer; iv. missing (employed in the Public Administration, working as an independent worker, unemployed or out of the labor force). After excluding all firms without fixed-term contract employees and all observations with missing values for any of the regressors, the final dataset contains 80,840 observations.

\section{Results}

\subsection{The hiring stage}

Who hires temporary workers?

In this section we report the results of the estimation of the first beta-binomial regression model. The dependent variable $(Y)$ is the number of workers at the firm that have a fixed-term contract and the size of the risk set $(n)$ corresponds to the total number of employees at the same firm, which is also an upper bound on the number of fixed-term contracts that the firm may offer at any time. ${ }^{9}$ The vector $x$ is a set of variables that account for the characteristics of the firm and its workforce. The estimation results are provided in Table 1.

\footnotetext{
${ }^{9}$ It could be argued that some workers were hired prior to the introduction of fixed-term contracts and therefore could not have been offered such contracts. However, because fixed-term contracts were introduced in Portugal as early as 1978 and a cap on their duration always existed (and never execeeded three years over the sample period) it is adequate to assume that the inability to use fixed-term contracts some twenty years prior to the period we study is irrelevant to the problem we are addressing. We are assuming that all workers could have a fixed-term contract if the firm dismissed all workers with permanent contracts and hired replacement workers.
} 


\begin{tabular}{|c|c|c|c|}
\hline parameter & estimate & std. error & marg. effect \\
\hline \multicolumn{4}{|l|}{ Skill-composition (\%) } \\
\hline Managers & $-4.190^{*}$ & 0.642 & -2.733 \\
\hline Top executives & $-1.473^{*}$ & 0.178 & -0.961 \\
\hline Intermediate executives & $-2.273^{*}$ & 0.159 & -1.483 \\
\hline Supervisors and team leaders & $-0.975^{*}$ & 0.186 & -0.636 \\
\hline Highly skilled professionals & $-1.222^{*}$ & 0.133 & -0.797 \\
\hline Skilled professionals & $-0.616^{*}$ & 0.131 & -0.401 \\
\hline Semi-skilled professionals & -0.068 & 0.139 & -0.044 \\
\hline \multicolumn{4}{|l|}{ Firm size (nr. of workers) } \\
\hline $500-999$ & 0.042 & 0.035 & 2.768 \\
\hline 1000 and more & $-0.165^{*}$ & 0.043 & -10.299 \\
\hline \multicolumn{4}{|l|}{ Firm Age } \\
\hline $2-5$ years & $-0.230 *$ & 0.090 & -14.044 \\
\hline 5 and more & $-0.287^{*}$ & 0.086 & -17.232 \\
\hline age unknown & $-1.369^{*}$ & 0.351 & -58.434 \\
\hline Wage dispersion $(t-1)$ & $0.092^{* *}$ & 0.004 & 0.060 \\
\hline Wage dispersion unknown & $0.133^{*}$ & 0.027 & 9.008 \\
\hline Training costs per worker $(\log )$ & $-0.016^{*}$ & 0.005 & -0.875 \\
\hline \multicolumn{4}{|l|}{ Age structure of the workforce } \\
\hline$\%$ between 25 and 44 & $-3.039 *$ & 0.118 & -1.982 \\
\hline$\%$ between 45 and 64 & $-4.592^{*}$ & 0.102 & -2.995 \\
\hline$\% 65$ and over & -0.970 & 0.794 & -0.633 \\
\hline Voluntary quits (\%) & $0.261^{*}$ & 0.071 & 0.170 \\
\hline Separations due to demographics (\%) & $1.113^{* * *}$ & 0.645 & 0.726 \\
\hline Hours worked (\%) & $0.559^{*}$ & 0.113 & 0.365 \\
\hline Male workers (\%) & $0.544^{*}$ & 0.038 & 0.355 \\
\hline intercept & $1.652^{*}$ & 0.189 & \\
\hline$\alpha$ & 0.960 & 0.098 & \\
\hline Year Dummies & YES & & \\
\hline Industry Dummies & YES & & \\
\hline $\mathrm{N}$ & 12079 & & \\
\hline $\log \mathrm{L}$ & -56241.1 & & \\
\hline
\end{tabular}

Table 1: Determinants of the Use of Fixed-Term Contracts - Beta-Binomial ReGRESSION MODEL. ${ }^{*}, * *, * * *$ denote statistical significance at 1,5 and 10 percent, respectively .

The first set of variables we want to consider are those that proxy for human capital intensity. These variables are the proportion of workers classified in each skill-level and training costs per worker (in logs). Eight skill-levels were considered. ${ }^{10}$ The reference category is that of Apprentices.

The results indicate that human capital intensity and fixed-term contracts move

\footnotetext{
${ }^{10}$ All workers are administratively assigned one skill-level out of eight possibilities on the basis of their occupation and level of education. The eight skill-levels are: top executives, intermediate executives, supervisors and team leaders, highly-skilled professionals, skilled professionals, semi-skilled professionals, non-skilled professionals, and apprentices, interns and trainees.
} 
in opposite directions. Firms with a larger share of workers near the top-end of the skills distribution are less likely to use temporary contracts. Increasing by one percentage point the share of Top Cadre employees reduces by 2.7 the number of temporary contracts at the firm (i.e. by 3.9 percent of the average count). ${ }^{11}$

As we have discussed previously, the choice of the contract the firm offers when hiring new employees crucially depends on its hiring technology. Firms may choose between high and low hiring cost strategies, which will produce different results in terms of the quality of the matches being formed (greater if more pre-hiring screening is done). The choice of the hiring technology will depend on the costs of failure, which will depend on the cost of keeping the wrong match on the job and on the type of contract offered to newly admitted workers. The cost of failure increases as we move up in firms' hierarchy of positions, a fact well-known in the span-ofcontrol literature (Rosen, 1982). This implies that workers hired to fill higherrank positions (typically, more skilled workers) are likely to pass through a more demanding screening process aimed at minimizing the risk of failure. Still, if bad matches are formed, they will be quickly undone because the cost of keeping the match is more likely to exceed the cost of dismissal. Termination of new contracts within a short time means that it occurs within the trial period when the firing cost advantage of fixed-term contracts is minimum. ${ }^{12}$ The two arguments imply that highly skilled workers are more likely to be hired on open-ended contracts. However, even if they are hired with a fixed-term contract, the promotion decision is expected within a short time. In any case, firms with a more skilled workforce are expected to have a smaller fraction of fixed-term contracts because they offer openended contracts to their newly-admitted workers more frequently and because they make the decision to terminate the temporary match or convert it to permanent sooner rather than later. This is, indeed, what our estimation results indicate.

Human capital intensity is likely to influence the employer's choice between

\footnotetext{
${ }^{11}$ All marginal effects were computed for the mean value of all continuous variables in the regressors set and for the omitted category of all dummy variables. The estimated count at the mean is 68.6 for an average risk set of 374.2 , corresponding to an estimated proportion of fixed-term contracts of 18.3 percent.

${ }^{12}$ Since 1991, the length of the trial period for workers hired with open-ended contracts varies with the complexity and responsibility of the tasks being performed. For top executives it is four times as long as it is for unskilled or semi-skilled workers; for highly skilled workers it is three times as long.
} 
temporary and open-ended contracts for two other reasons. First, more skilled workers receive higher wages. To the extent that firing costs have a component that varies with the worker's wage, as they typically do, this will imply that firing costs are increase with the worker's skill. In such circumstances, low-firing cost contracts are specially valued and employers should prefer hiring their skilled workers with temporary contracts. However, higher human capital intensity also implies more stable employment relations, because firing a skilled worker implies the loss of all shared investments (training included). The more skilled workers are, the more likely it is that the latter component of the firing cost dominates the former. Hence, we expect that firms that employ skilled workers more intensively will also employ a smaller fraction of their employees with temporary contracts.

A variable measuring training costs per worker (in logs) was also included in the regressors set. It is computed as the ratio between the firm's total expenditure on training and the firm's total number of workers. We would like to include in the regression the amount of training given to newly-hired and tenured workers, but separately. Unfortunately, we do not have information on the type of training firms pay for. Therefore, all we can establish at this point is that firms that invest more in training also employ fewer workers with fixed-term contracts - a one percent increase in training expenditures per capita reduces the fixed-term contract count by 0.875 . Standard human capital theory implies that training intensive firms will hire their employees on permanent contracts or on temporary contracts that are rapidly terminated or transformed into permanent. However, if training is an ability screen, as in Author (2001), its relationship with temporary forms of employment is totally reversed. In this case, employers adopt less intensive prehiring screening strategies and screen bad matches out as their newly-admitted workers go through on-the-job training programmes. In this case, more training implies a greater use of fixed-term contracts. However, a positive association between training and fixed-term contract use would also be consistent with training intensive firms using a fringe of temporary workers to insulate their permanent and highly trained workers from the alias of economic conditions. Hence, the result 
we obtain, although consistent with an human capital interpretation, does not preclude the possibility of fixed-term contracts being used to screen workers for permanent positions.

The two sets of results above indicate that the more skilled the firm's workforce is the less it will use fixed-term contracts. Still, we cannot tell whether this is because human capital intensive firms do not use temporary contracts to screen workers to permanent positions, regardless of the skill content of those positions, or because they simply hire fewer low-skilled workers. ${ }^{13}$ Only by looking at the flow of new admissions and transitions out of temporary employment (which we do below) will we be able to sort out the two alternatives.

Direct evidence on the screening role of fixed-term contracts is obtained by including in the set of regressors two variables that measure the proportion of permanent workers that leave the firm either voluntarily or because of 'natural' causes (old age and death). Both are taken as proxies for the number of permanent positions opened at the firm and both coefficients are positive and significant.

If fixed-term contracts are used to fill permanent positions, then the number of permanent vacancies will have a positive effect on both the share of temporary contracts and the proportion of fixed-term contracts converted into open-ended contracts. No significant relationship should emerge if fixed-term contracts did not play a screening role. The above-mentioned relationship between open vacancies and fixed-term contracts is expected to hold only if those vacancies were not opened because of the firm's previous firing decisions. This means that we would like to exclude separations by mutual consent and early exits into retirement. The number of permanent workers who left the firm during the calendar year voluntarily as well as the number of those who left into retirement due to old age and those who died are reasonably good proxies for the number of permanent positions open at the firm level. ${ }^{14}$

If fixed-term contracts are used to screen workers for permanent positions, we

\footnotetext{
${ }^{13}$ Recall that we are controlling for the skill-structure of the stock, not the flow, of workers.

${ }^{14}$ For the universe of Portuguese firms with at least 100 employees, the voluntary quit rate of workers with an open-ended contract is 5.5 percent. Exits into retirement and workers' deaths account for 8.3 and 1.6 percent, respectively, of the total number of separations of workers with such contracts.
} 
expect more separations of permanent workers for these two reasons to imply a greater number of temporary workers (replacement hires) and a greater rate of promotion of temporary workers to permanent positions. Our results indicate that when the proportion of permanent workers that leave for natural causes and voluntarily increases by one percentage point, the expected number of temporary contracts at the firm also rises by 0.726 and 0.170 , respectively. This also indicates that fixed-term contracts are used as mechanisms for screening. However, this indication may only be confirmed or not when we consider the promotion stage.

The regression equation also contains a number of other covariates that seek to control for other relevant firm characteristics - firm age (younger firms facing more volatile environments), wage dispersion (controlling for union strength as stronger unions are associated with reduced wage dispersion - Freeman, 1982, Cardoso and Portugal, 2005), the age structure of the workforce, the share of male workers, the percentage of hours actually worked relative to the maximum possible considering the number of workers and the maximum length of their work week (which proxies for temporary variations of the workload), and firm size. ${ }^{15}$ The signs of the regression coefficients are in accordance with expectations. In particular, it is worth noticing that the estimate obtained for the coefficient of the wage dispersion variable is consistent with unions opposing the use of 'precarious' forms of contract for all workers rather than with the alternative (unions aiming at protecting the employment of their constituency, dominated by core-permanent workers, at the expense of those newly-arrived on the labor market or re-entering it).

\section{Who gets a temporary contract?}

The evidence reported in the previous section refers to the firm-level stock of temporary contracts. In this section we use employee-level data obtained from the first matched employer-employee dataset described in Section 3.2 to look at

\footnotetext{
${ }^{15}$ The firm's age enters the regression as a qualitative variable with three categories: less than two years (omitted), between two and five and more than five years old. Four intervals were considered for the employees' age variable: less than 25 (omitted), between 25 and 64 and over 64 . Three dummy variables - between 100 and 499 workers (omitted), between 500 and 999 workers, and 1000 workers and more - control for firm size).
} 
the flow of new admissions (workers admitted in the three-month period prior to the observation point). With these data we estimate a Probit model for the probability that the new match is formed as temporary, i.e., the newly-admitted worker is offered a fixed-term contract.

To identify the effect of employers' characteristics on workers' outcomes we want to control for worker attributes that are likely to influence the probability of working with temporary contracts. We know from a different study (Varejão and Portugal, 2005) that workers with fixed-term contracts in Portugal are predominantly female, young (below the age of 35), and that they have low levels of education. In our empirical model we do not want to control for the workers' skill, but only for those attributes that are individual-specific (age, gender and education). ${ }^{16}$ Besides, as immigrants are also known to be more likely to work with temporary contracts (Fernández and Ortega, 2006), we will also control for nationality status (nationals versus non-nationals).

Standard labor demand theory implies that the choice between hours and employees hinges on the relative costs of the two margins of adjustment. In particular, for the same hiring and firing costs of temporary workers, the employer's choice will be biased toward adding more (temporary) workers as an alternative to adding extra hours if the cost of overtime hours is greater (see Gramm and Schnell, 2001). Therefore, we will include one variable that measures the cost of overtime hours. We will also control for the wages of permanent workers at the firm as the higher these wages are, the greater the employer propensity will be to use the less costly temporary workers and to keep them as temporaries for as long as possible, or else have them leave.

Finally, considering our previous discussion of the role that human capital and training play in the hiring process, we also want to include a measure of training intensity in order to assess its impact on the hiring policy of the firm.

In Table 2 we report the results of the estimation of the Probit model for the probability that a worker is hired as temporary as opposed to permanent.

\footnotetext{
${ }^{16}$ Because skill levels are determined by workers' attributes (education and experience) as well as by their occupation and tenure, which are job-related, we do not include them in the regressor set.
} 


\begin{tabular}{|l|r|r|r|}
\hline & estimate & std. error & mg. effect \\
\hline \hline Intercept & 1.092 & 0.054 & \\
Schooling & & & \\
6 years & $0.312^{*}$ & 0.030 & 0.058 \\
9 years & $0.376^{*}$ & 0.029 & 0.067 \\
12 years & $0.186^{*}$ & 0.030 & 0.037 \\
College & $-0.378^{*}$ & 0.036 & -0.101 \\
Gender (Male=1) & -0.013 & 0.020 & -0.003 \\
Immigrants & $0.104^{*}$ & 0.031 & 0.022 \\
Workers' Age & & & \\
$20-25$ & 0.051 & 0.044 & 0.011 \\
$25-30$ & $-0.079^{* * *}$ & 0.044 & -0.018 \\
$30-35$ & $-0.307^{*}$ & 0.045 & -0.079 \\
$35-40$ & $-0.446^{*}$ & 0.047 & -0.123 \\
$40-45$ & $-0.498^{*}$ & 0.049 & -0.140 \\
$45-50$ & $-0.486^{*}$ & 0.052 & -0.136 \\
$50-55$ & $-0.624^{*}$ & 0.058 & -0.183 \\
$55-60$ & $-0.813^{*}$ & 0.071 & -0.254 \\
60 and over & $-0.744^{*}$ & 0.086 & -0.228 \\
Training costs per worker (log) & $0.018^{*}$ & 0.005 & 0.004 \\
Firm size (nr. of workers) & & & \\
$500-999$ & $0.183^{*}$ & 0.029 & 0.037 \\
1000 and more & $-0.096^{*}$ & 0.022 & -0.022 \\
Permanent workers' monthly wage & $0.0001^{*}$ & 0.000 & 0.0000 \\
Overtime hour cost & $-0.034^{*}$ & 0.004 & -0.008 \\
No overtime firm & $-0.165^{*}$ & 0.030 & -0.040 \\
\hline N & 30,963 & & \\
Log likelihood & -13551.85 & & \\
\hline
\end{tabular}

Table 2: Probability of Being hired with a fixed-term contract - Probit Model. $*, * *, * * *$ denote statistical significance at 1, 5 and 10 percent, respectively. Age intervals are closed on the left.

The estimates obtained for the coefficients of the variables that represent employees' characteristics are consistent with the well-known profile of temporary workers. Female workers, immigrants and low-educated workers are all more likely to be hired on a temporary contract than otherwise similar workers by similar firms.

Workers' age has a decisive effect on the type of contract they are more likely to be offered. In the probit model we have included a set of nine age dummies that take the value one if the worker falls into the corresponding age interval (all brackets, except the last, have a five-year width starting at the age of 20; the omitted category is below 20). The probability of receiving a temporary contract 
decreases with the worker's age for every age interval considered above the age of 25. Evaluated at the sample average of the continuous regressors and for the omitted categories of the qualitative variables (including age - below 20), the estimated probability of being hired with a fixed-term contract is 86.1 percent (the sample average is 79.1 percent). However, this probability drops off substantially for workers aged at or above 25 . It is 55.4 per cent for workers with similar characteristics but aged between 30 and 35, and 23.7 per cent for individuals in the 50-55 age bracket. While this probability remains high for individuals in all age groups, it is clear that it is at the early stages of participation in the labor market that fixed-term contracts are more frequently offered and accepted. This is an indication of these contracts being used for screening workers for permanent positions as younger workers are less able to convey relevant information to the labor market and are more likely to be in a job shopping situation. If other reasons - staffing for temporary positions or churning - were to dominate the probability of receiving a fixed-term contract, we would not expect it to vary across age groups as much as it does.

The higher the wages paid to permanent employees are and the more resources the firm devotes to training its workforce, the more likely it is that fixed-term contracts will be used for new admissions.

The results also show that the probability of being hired with a fixed-term contract is reduced by 4.0 percentage points if the hiring firm did not use overtime work in the past (the year before the hirings occur). To the extent that overtime work is the employer's first response to temporary increases in the workload or increases of an uncertain duration, this is an indication that firms facing more stable environments also use permanent contracts more frequently when hiring.

\subsection{The promotion stage}

Who promotes temporary workers to permanent positions?

In this subsection we look at the rate at which firms convert fixed-term contracts 
into open-ended contracts. Our aim is to set the profile of those employers who are more likely to make that decision. To do that, we estimate the second betabinomial regression model referred to in Section 2.1. The dependent variable is the number of workers with fixed-term contracts that obtained an open-ended contract during the calendar year, the size of the risk set being the total number of fixedterm contracts that existed at any point in time within the same year, which is also the upper bound for the number of contract conversions that are feasible in every period. As before, $x$ is a set of variables that account for the characteristics of the firm and the workforce. In addition to the same variables used in the first beta-binomial model, $x$ now also includes one control for the average of the hourly base wage (in logs) computed at the firm level, as well as controls for the tenure structure of the workforce. Results are reported in Table 3.

At the sample mean of the continuous regressors and for the omitted category of all qualitative regressors, the estimated probability of a fixed-term contract being converted to permanent is $18.6 \%$ (the corresponding sample mean is $18.0 \%$ ). Controlling for firms' size and age, and including year and industry dummies, human capital intensive firms are those that promote temporary workers to permanent positions more often. Increasing by 1 percentage point the proportion of intermediate executives or supervisors and team leaders at the firm raises the estimated count of temporary contracts that become permanent by 0.218 and 0.142 , respectively. ${ }^{17}$

Fixed-term contracts are also more likely to end with a conversion to an openended contract among firms that invest more in training. The marginal effect is 0.636 more contracts converted for each 1 percent increase in training per worker (temporary or not). The same positive effect is also obtained for wages even after controlling for all the relevant firm and workforce characteristics.

These results are all consistent with fixed-term contracts being used for screening (and as a complement of training). If anything, they allow for another type of use of fixed-term contracts (churning or buffer-stock) only in the case of low-skill

\footnotetext{
${ }^{17}$ Increasing the share of employees at the very top of the skill structure has a smaller effect on contract conversion than it has at the middle. However, at the top levels - managers and top executives - the proportion of workers admitted with fixed-term contracts is very small.
} 


\begin{tabular}{|c|c|c|c|}
\hline & estimate & std. error & mg. effect \\
\hline \multicolumn{4}{|l|}{ Skill-composition (\%) } \\
\hline Managers & 0.167 & 1.064 & 0.028 \\
\hline Top Executives & 0.089 & 0.277 & 0.015 \\
\hline Intermediate Executives & $1.305^{*}$ & 0.232 & 0.218 \\
\hline Supervisors and team leaders & $0.846^{*}$ & 0.264 & 0.142 \\
\hline Highly skilled professionals & $0.591^{*}$ & 0.171 & 0.099 \\
\hline Skilled professionals & $0.393^{* *}$ & 0.164 & 0.066 \\
\hline Semi-skilled professionals & 0.215 & 0.169 & 0.036 \\
\hline \multicolumn{4}{|l|}{ Firm size (nr. of workers) } \\
\hline 500-999 & $0.099^{* *}$ & 0.047 & 1.699 \\
\hline 1000 and more & 0.521 & 0.056 & 9.603 \\
\hline \multicolumn{4}{|l|}{ Firm age } \\
\hline $2-5$ years & -0.039 & 0.224 & -0.648 \\
\hline 5 and more years & -0.209 & 0.219 & -3.327 \\
\hline age unknown & 0.633 & 0.427 & 11.851 \\
\hline Wage dispersion (t-1) & $-0.015^{*}$ & 0.005 & -0.266 \\
\hline Wage dispersion unknown & $-0.196^{*}$ & 0.040 & -3.135 \\
\hline Training costs per worker (log) & $0.038^{*}$ & 0.007 & 0.636 \\
\hline Hourly wage (log) & $0.107^{*}$ & 0.029 & 1.797 \\
\hline \multicolumn{4}{|l|}{ Tenure structure (\%) } \\
\hline 2 years or less & $-0.932^{*}$ & 0.094 & -0.156 \\
\hline $2-5$ years & $1.602^{*}$ & 0.136 & 0.268 \\
\hline \multicolumn{4}{|l|}{ Workers' age structure (\%) } \\
\hline $25-44$ years & -0.008 & 0.176 & -0.001 \\
\hline $45-64$ years & $-0.402^{* *}$ & 0.173 & -0.067 \\
\hline 65 and over & -0.226 & 1.145 & -0.038 \\
\hline Male workers (\%) & -0.055 & 0.064 & -0.009 \\
\hline Separations due to demographics (\%) & 2.137 & 1.263 & 0.358 \\
\hline Voluntary quits (\%) & $0.381^{* *}$ & 0.179 & 0.064 \\
\hline Hours Worked (\%) & 0.130 & 0.210 & 0.022 \\
\hline Constant & -1.626 & 0.342 & \\
\hline$\alpha$ & 1.934 & 0.031 & \\
\hline Year dummies & Yes & & \\
\hline Industry dummies & Yes & & \\
\hline
\end{tabular}

Table 3: Determinants of the conversion of Fixed-Term Contracts into OpenEnded Contracts - Beta-Binomial Regression Model. *, **, *** denote statistical significance at 1,5 and 10 percent, respectively.

jobs/firms.

The very same indication is implied by the estimates obtained for the tenure structure. A greater share of workers with tenure between two and five years (most fixed-term contracts have a maximum duration of three years) increases significantly the number of fixed-term contracts that are converted into open- 
ended contracts. A one percentage point increase in the proportion of workers with less than two years of tenure reduces, relative to the omitted category (more than five years) the count of contracts transformed into open-ended contracts by 0.156 (slightly more than one percent of the average count, which is 14.9). On the contrary, a greater proportion of workers with two to five years of tenure increases the predicted count (the estimated marginal effect is 0.268).

The number of permanent positions opened due to exits into retirement or to the death of the worker and, in particular, job openings due to voluntary quits of workers with permanent contracts, also increase the expected conversion of temporary contracts into open-ended contracts $(0.064$ more contracts being converted into open-ended for an additional 1 percentage point of permanent workers leaving the firm voluntarily).

Recall that permanent positions that become vacant were also found to have a positive effect on the number of admissions with fixed-term contracts. Together, these two results describe the employer's dominant strategy when they recruit for a permanent position - typically they offer an initial temporary contract with the promise of a promotion to an open-ended contract if the match proves good enough. This is consistent with Nagypál's (2001) description of the process of learning about match quality. In conjunction with our results on the effects of training intensity, this result is also consistent with Autor's (2001) finding that temporary employment is a mechanism of recruitment for permanent positions and training is an ability screen.

We can also see the importance of the screening role of temporary contracts by looking at the effect of the Hours Worked variable on both admissions and promotions. This variable measures the proportion of the maximum number of normal hours that the firm can obtain from its stock of workers that was actually used. It is thus an indicator of how distant the firm is from its production frontier. We have seen before that the higher the proportion of actual hours is in relation to the maximum, the more the firm will hire with fixed-term contracts. This is what we would expect if the increase in the workload is of an uncertain duration. However, 
here we also see that when these circumstances prevail, firms are also expected to promote more temporary workers to permanent positions. Meaning that fixedterm contracts are used as devices for screening workers for permanent positions especially when the economic environment they operate in is more uncertain.

\section{Who gets promoted from temporary to permanent positions?}

To study transitions out of temporary employment spells, we estimated the complementary log-log hazard model described in Section 2.2. Three possible exit modes were considered - promotion to a permanent position without switching employers, transition to a different employer, and exit from dependent employment in the private sector. The first type of transition is the one that contains more information on the type of use employers make of fixed-term contracts. Hence, the corresponding results are the only ones that are reported here.

The regressor set contains the same variables as in the probit model in the previous section. These include both worker characteristics and employer characteristics. Because the probabilities attached to the alternative exit modes may be determined by the number of fixed-term contracts that exist at the firm at the moment the transition is observed, we add a control for this number (the 'fixedterm contract' variable). To circumvent the possibility that this variable could be endogenous, we also included in the equation the estimation residuals of the beta-binomial model for the stock of fixed-term contracts at the firm discussed in Section 4.1 (see Train, 2008).

Schooling and age are two important determinants of the employment prospects of temporary workers. The probability that a worker will obtain a permanent contract from his or her employer is 3 to 5 percentage points above the baseline age category (less than 20) until the age of 35-40. Thereafter, that probability declines very rapidly. The effect of age becomes negative above the age of 50. It is especially strong and significant for all workers above the age of $60 .{ }^{18} \mathrm{~A}$ transition to an open-ended contract is also more likely for more educated workers - the effect

\footnotetext{
${ }^{18}$ In these age intervals, employees are less likely to make a transition to all destinations considered. Put differently, these are the workers that face the highest probability of remaining in temporary employment.
} 


\begin{tabular}{|c|c|c|c|}
\hline & estimate. & std. error & mg. effect \\
\hline Gender $($ Male $=1)$ & -0.005 & 0.018 & -0.001 \\
\hline Schooling & & & \\
\hline 6 years & 0.013 & 0.029 & 0.002 \\
\hline 9 years & 0.017 & 0.029 & 0.002 \\
\hline 12 years & $0.070^{* *}$ & 0.029 & 0.010 \\
\hline College & $0.271^{*}$ & 0.036 & 0.043 \\
\hline Immigrant Status & $-0.346^{*}$ & 0.032 & -0.045 \\
\hline Workers' age & & & \\
\hline $20-25$ & $0.255^{*}$ & 0.040 & 0.039 \\
\hline $25-30$ & $0.354^{*}$ & 0.041 & 0.056 \\
\hline $30-35$ & $0.308^{*}$ & 0.043 & 0.049 \\
\hline $35-40$ & $0.195^{*}$ & 0.047 & 0.030 \\
\hline $40-45$ & $0.185^{*}$ & 0.051 & 0.029 \\
\hline $45-50$ & $0.071^{*}$ & 0.058 & 0.011 \\
\hline $50-55$ & -0.031 & 0.070 & -0.004 \\
\hline $55-60$ & -0.146 & 0.094 & -0.020 \\
\hline 60 and over & $-0.602^{*}$ & 0.162 & -0.069 \\
\hline Tenure (in quarters) & & & \\
\hline Tenure $=2$ & $0.576^{*}$ & 0.041 & 0.100 \\
\hline Tenure $=3$ & $1.098^{*}$ & 0.039 & 0.224 \\
\hline Tenure $=4$ & $1.605^{*}$ & 0.037 & 0.383 \\
\hline Tenure $=5$ & $1.866^{*}$ & 0.035 & 0.466 \\
\hline Tenure $=6$ & $1.766^{*}$ & 0.037 & 0.439 \\
\hline Tenure $=7$ & $1.710^{*}$ & 0.038 & 0.423 \\
\hline Tenure $=8$ & $2.124^{*}$ & 0.039 & 0.581 \\
\hline Tenure $=9$ & $0.714^{*}$ & 0.100 & 0.139 \\
\hline Tenure $=10$ & $0.719^{*}$ & 0.114 & 0.140 \\
\hline Tenure $=11$ & $1.131^{*}$ & 0.097 & 0.255 \\
\hline Tenure $=12$ & $0.366^{* * *}$ & 0.221 & 0.062 \\
\hline Firm size (nr. of workers) & & & \\
\hline $500-999$ & -0.007 & 0.025 & -0.001 \\
\hline 1000 and more & -0.022 & 0.027 & -0.003 \\
\hline Training costs per worker (log) & $0.086^{*}$ & 0.005 & 0.013 \\
\hline Permanent workers' pay & $-0.001^{*}$ & 0.000 & -0.0001 \\
\hline Overtime hour cost & $0.018^{*}$ & 0.003 & 0.003 \\
\hline No-overtime firm & $-0.128^{*}$ & 0.029 & -0.018 \\
\hline Nr. of Fixed-term contracts & $0.0002^{*}$ & 0.000 & 0.000 \\
\hline Fixed-term contracts residual & $-0.0001^{* *}$ & 0.000 & -0.0001 \\
\hline Intercept & $-3.120^{*}$ & 0.058 & \\
\hline Industry dummies & Yes & & \\
\hline Nr. of observations & 70,594 & & \\
\hline Log Likelihood & $-31,087.8$ & & \\
\hline
\end{tabular}

Table 4: Transitions from a Fixed-Term Contract to an Open-ended Contract Complementary Log-Log Model. * , **, *** denote statistical significance at 1, 5 and 10 percent, respectively . 
of education is significantly different from zero only for workers with 12 years of schoolling or, especially, college education.

The conversion of fixed-term contracts into open-ended contracts follows a clear time pattern. The probability that such a conversion occurs starts at a very low level but it increases very quickly after a 6-month period. Moreover, it has two peaks - the first at the fifth quarter of duration of the contract and the second at the eighth, that is, approximately when the contract reaches the end of its first and second year of duration. By the end of the third year of contract, the probability that the worker will get promoted to a permanent position is below its starting level. This is only partially coincident with the pattern reported by Güell and Petrongolo (2003). These authors find that the conversion of temporary contracts has a marked spike at their legal maximum duration, which is not what we observe in the Portuguese case. While in Spain, promotion from a temporary contract to a permanent position is attributed to the quit threat workers can exert (which depends on their outside options), in Portugal the time-shape of the hazard function hints at promotions being predominantly driven by the employers' staffing strategy - promotions take place in specific moments of the temporary contract life, not at its legal limit. However, as in Spain, different types of workers face different outside options, and that also influences their promotion prospects. Age and education emerge as the two most important determinants of the probability of receiving an open-ended contract, which is consistent with what we know on how labor market opportunities change over time and across workers.

Immigrant workers are significantly less likely than natives to make a transition from a temporary to an open-ended contract. For a predicted transition probability of 16 percent, the effect of immigrant status is -4.5 percent.

Looking now at the employer side, we find that firm-provided training has a positive effect on the probability of a temporary worker being promoted to a permanent position - a 1 per cent increase in the amount of per capita training costs increases the probability of promotion by 1.3 percent. In Section 4.1 we saw that high-training employers are intensive users of fixed-term contracts when hiring 
new employees. At that stage, we could not conclude why this was so, whether it was because they were screening on-the-job workers that would be too costly to dismiss if they hired them as permanent from the outset, or because they responded to positive shocks, hiring a fringe of temporary workers that they would dismiss as shocks were reversed. Here, we see that these firms are more likely to offer open-ended contracts to those workers that they hire with fixed-term contracts. This is an indication of temporary contracts being used for screening workers to temporary positions by human capital intensive firms.

The importance of fixed-term contracts as screening devices is further highlighted by the fact that the firm-level number of such contracts also has a positive, albeit small, effect on the probability of being promoted to a permanent position. We would not anticipate a large effect associated with the number of fixed-term contracts because, even if screening were the only reason that employers used fixed-term contracts, a non-trivial portion of these contracts would end with a termination because they would be considered not-good-enough matches.

Other results indicate that workers who are hired as temporary by high-wage employers (i.e. employers that pay higher unconditional wages to their permanent employees) face poorer prospects of obtaining an open-ended contract from those same employers. But those that are hired into organizations where the cost of overtime work is higher are in the opposite situation. These results are a manifestation of the other uses fixed-term contracts are given. Uncertainty and labor costs attached to permanent workers/positions, although seemingly dominated by screening, are also behind the recruitment of temporary workers.

\section{Conclusion}

This article studies the use that employers make of fixed-term contracts and their effects on workers' employment status and prospects. We consider two crucial moments of the (temporary) employment relationship: the hiring stage and the promotion stage. We find that the nexus between human capital variables - schooling, skills and employer-provided training - and firm-level use of fixed-term contracts 
is paramount at both stages.

At the hiring stage, we find that human capital intensity and the firm-level fraction of temporary contracts move in opposite directions. Still at this stage, we also find that the workers' age has a decisive effect on the type of contract that they are offered, the probability of receiving a temporary contract sharply decreasing with age.

When we turn to the promotion stage, we find that the profile of employers that make the most intense use of fixed-term contracts matches the profile of those employers that offer a permanent position to their temporary workers more often.

There is also clear evidence indicating that both age and schooling are major determinants of the outcome of temporary employment spells, older and less educated workers being less likely to be offered permanent contracts.

When a permanent position opens up, employers respond by offering temporary contracts to new-hires and, should that prove to be the right option, convert them into open-ended contracts after a trial period. The length of the trial period varies with the workers' skills and education - it is shorter for more skilled and more educated workers. Promotions to permanent positions are driven by employers' staffing policies and are more likely to occur in the first two years of contract, i.e., before its maximum duration is reached.

Despite the specific nature of the institutions governing the Portuguese labor market, our results are remarkably consistent with previous research focusing on the U.S. and some European countries, which conclude that temporary forms of employment are used to screen workers for permanent positions, with on-the-job training serving as an ability screen. 


\section{References}

Autor, David H. (2001), Why Do Temporary Help Firms Provide Free General Skills Training?, Quarterly Journal of Economics, 116 1409-48.

Blanchard, Olivier and Augustin Landier (2002), The Perverse Effects of Partial Labor Market Reform: Fixed Duration Contracts in France, Economic Journal, 112 F214-F244.

Blanchard, Olivier And Pedro Portugal (2001), What Hides Behind an Unemployment Rate: Comparing Portuguese and U.S. Labor Markets, American Economic Review, 91 187-207.

Burgess, Simon, Julia Lane, And David Stevens (2000), Job Flows, Worker Flows and Churning, Journal of Labor Economics, 18 473-502.

Cardoso, Ana Rute, And Pedro Portugal (2005), Contractual Wages and the Wage Cushion Under Different Bargaining Settings, Journal of Labor Economics, 23 875-902.

Faccini, Renato (2007), Reassessing Labor Market Reforms: Temporary Contracts as a Screening Device, mimeo.

Fernández, Cristina and Ana Carolina Ortega-Masague (2006), Labour Market Assimilation of Immigrants in Spain: Employment at the Expense of Bad Job-Matches?, IESE Business School Working Paper No. 644.

Freeman, Richard (1982), Union Wage Practices and Wage Dispersion within Establishments, Industrial and Labor Relations Review 36 3-21.

Gramm, Cynthia L. And John F. Schnell (2001), The Use of Flexible Staffing Arrangements in Core Production Jobs, Industrial and Labor Relations Review 54 245-258.

Güell, Maia And Barbara Petrongolo (2003), How Binding Are Legal Limits? Transitions from Temporary to Permanent Work in Spain, Labour Economics, 14 153-183. 
Heckman, James and Robert Willis (1977), A Beta-Logistic Model for the Analysis of Sequential Labor Force Participation Decisions by Married Women, Journal of Political Economy, 85 27-58.

Hunt, Jennifer (2000), Firing Costs, Employment Fluctuations and Average Employment: An Examination of Germany, Economica, 67 177-202.

Johnson, Norman L., Samuel Kotz and Adrienne W. Kemp (2005), Univariate Discrete Distributions, 3rd edition, Hoboken NJ: John Wiley \& Sons.

Lane, Julia, David Stevens, and Simon Burgess (1996), Worker and Job Flows, Economics Letters, 51 10-113.

Maurin, E. (2000), The European Paradox: Do Flexible Contracts Create Rigid Labor Markets?, INSEE Working Paper 2000-07.

NAGypál, Éva (2001), Fixed-term Contracts in Europe: A Reassessment in Light of the Importance of Match-specific Learning, mimeo.

OECD (2004), Employment Outlook, 2004, Paris: OECD.

OECD (1999), Employment Outlook, 1999, Paris: OECD.

Rosen, Sherwin (1982), Authority, Control and the Distribution of Earnings, Bell Journal of Economics, 13 311-323.

Santos Silva, J. M. C. and J. M. R. Murteira (2000), Estimation of Default Probabilities Using Incomplete Contracts Data, mimeo.

Train, Kenneth E. (2008), Discrete Choice Models with Simulations, 2nd edition, Cambridge Ma: Cambridge University Press.

Varejão, José and Pedro Portugal (2007), Employment Dynamics and the Structure of Labor Adjustment Costs, Journal of Labor Economics, 25 137-165. 
Varejão, José and Pedro Portugal (2005), Matching Workers to Jobs in the Fast Lane: The operation of fixed-term contracts, in Labour Supply and Incentives to Work in Europe, ed. Ramón Gómez-Salvador, Ana Lamo, Barbara Petrongolo, Melanie Ward and Etienne Wasmer, Cheltenham: Elgar. 